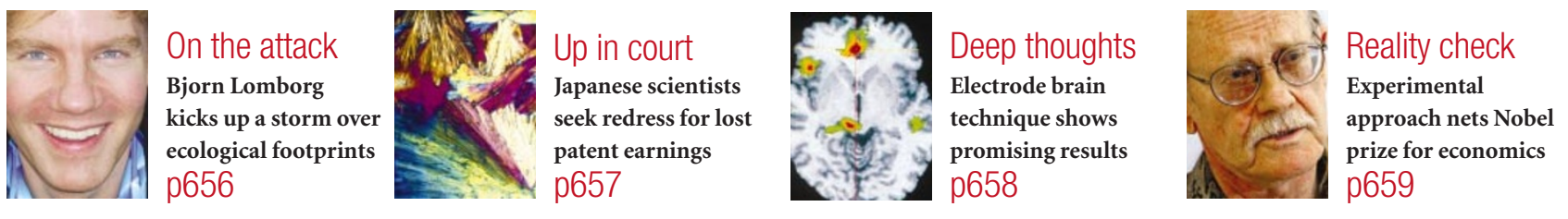

\title{
Superweed study falters as seed firms deny access to transgene
}

\section{Rex Dalton, San Diego}

Two major seed companies this week stand accused of hindering attempts to assess whether genetically modified sunflowers can turn their wild counterparts into 'superweeds'.

A team led by Allison Snow, a plant ecologist at Ohio State University in Columbus, has uncovered preliminary evidence that a transgene that confers insect resistance can increase the number of seeds produced by wild sunflowers. This could allow the wild plants to proliferate as weeds.

But Pioneer Hi-Bred International of Des Moines, Iowa, and Indianapolisbased Dow AgroSciences have now blocked a follow-up study by refusing to allow the team access to either the transgene or the seeds from the earlier study.

Snow revealed the problem on 13 October during a lecture on transgene research at the Seventh International Symposium on the Biosafety of Genetically Modified Organisms in Beijing. "It is very frustrating," she said in an interview before the lecture. "We want to do good science. But this is keeping us from answering questions we want to ask."

The transgenic sunflowers contain a gene from the bacterium Bacillus thuringiensis $(B t)$, which allows them to produce a natural insecticide. Determining the impact of such transgenes in gene flow to wild plants is the subject of an intense scientific and political debate as nations consider what transgenic crops can be safely planted.

The results of Snow's initial study were revealed this August at the Ecological Society of America's annual meeting in Tucson, Arizona, and have been accepted for publication in Ecological Applications. They suggest that if the $B t$ transgene were to migrate into wild sunflowers, the plants' resistance to insects would increase the number of seeds produced. At a site in Nebraska, seed production in wild sunflowers with the transgene rose by $55 \%$, although the results for plants at a site in Colorado were not statistically significant.

The refusal by Pioneer and Dow to pro-
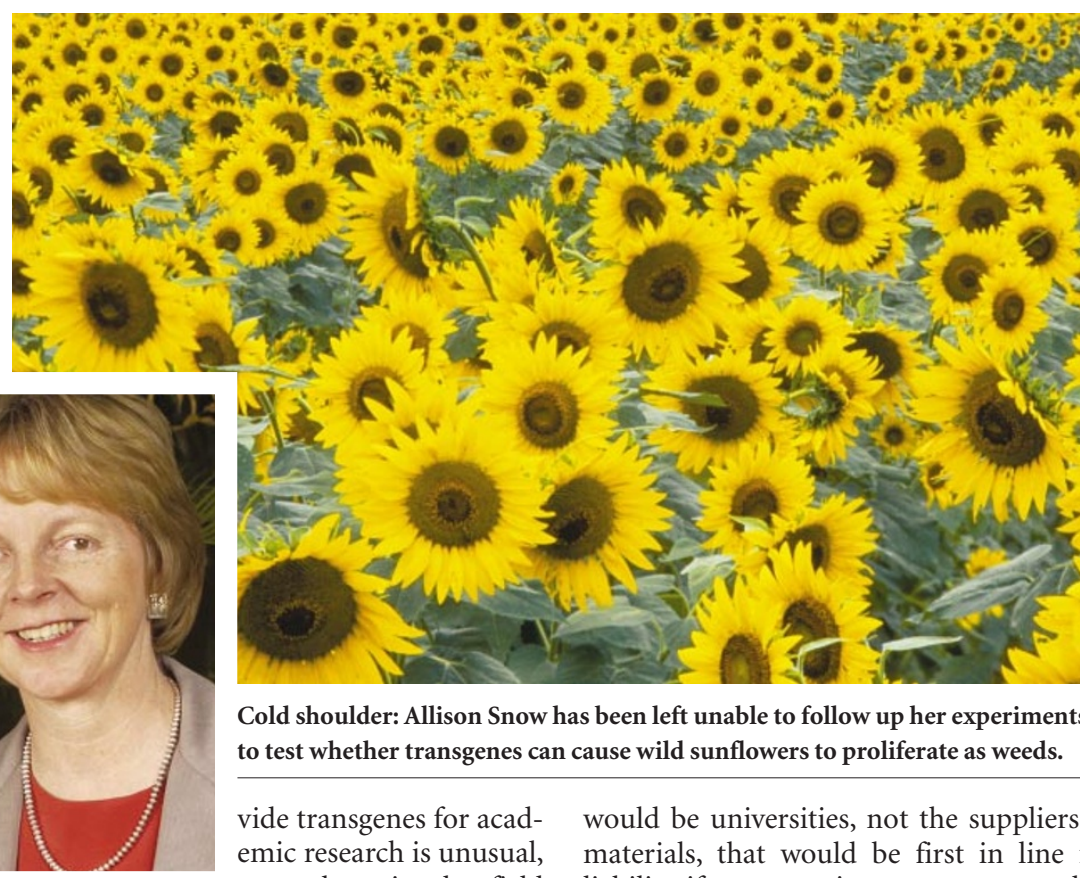

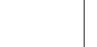

researchers in the field say. But Nature has identified at least one other recent case in which a plant geneticist at a leading US research university, who wanted to carry out an evolutionary study of Mexican maize, was denied access to transgenic material by two companies. That researcher does not want to be named.

Together with the US Department of Agriculture, Pioneer and Dow had funded Snow's study. But the seed firms say that they no longer want to continue the research because they do not plan to seek permission from the US government to sell transgenic sunflower seeds. Snow, however, wants to do further work, with purely academic funding, in an effort to confirm her initial findings.

Both seed companies confirm that they have refused to make the necessary materials available to Snow. "We would have to use time and talent to oversee the research," explains Doyle Karr, a spokesman for Pioneer. "We can't take the responsibility of putting the genes out if we aren't going to develop a product."

But critics of the company reject this. It 